\title{
Effect of zinc and boron on growth, yield and quality of tuberose (Polianthes tuberosa L.) cv. Prajwal
}

\begin{abstract}
The present investigation was carried out in the Department of Horticulture, Faculty of Agriculture, Annamalai University, Annamalai nagar during 2013-2015 in Randomized Block Design with eleven treatments and three replications. The eleven treatment combinations were formed by foliar application of zinc and boron viz., Zinc sulphate $(0.25,0.50$ and $0.75 \%)$ and Borax $(0.25,0.50$ and $0.75 \%)$ on 30,60 and 90 DAP, individually and incombination with 25 tha $^{-1}$ FYM and recommended dose of 200:200:200 $\mathrm{kg} \mathrm{ha}^{-1}$ NPK. The control was maintained with water spray.Various biometric observations on growth, yield and quality of tuberose were observed for all the treatments. Among the treatments, the biometric observations like plant height $(47.25 \mathrm{~cm})$, number of side shoots per plant (8.89), number of leaves per plant (36.19), plant spread $\left(24.50 \mathrm{~cm}^{2}\right)$, leaf area $\left(42.50 \mathrm{~cm}^{2}\right)$, chlorophyll content $\left(0.918 \mathrm{mgg}^{-1}\right)$ and dry matter production $\left(23.15 \mathrm{~g} \mathrm{plant}^{-1}\right)$ and yield attributes, viz., days to fifty per cent flowering (90.47 days), number of spikes per plant (4.55), spike length $(95.42 \mathrm{~cm})$, rachis length $(28.89 \mathrm{~cm})$, number of flowers per spike $(41.52)$, flower length $(6.66 \mathrm{~cm})$, flower diameter $(4.03 \mathrm{~cm})$, hundred flowers weight $(94.73 \mathrm{~g})$, flower yield per plant $(128.65 \mathrm{~g}$ plant $\left.{ }^{-1}\right)$, flower yield per plot $\left(1.54 \mathrm{~kg} \mathrm{plot}^{-1}\right)$, flower yield per hectare $\left(14.28 \mathrm{tha}^{-1}\right)$, number of bulbs and bulblets (18.23) and weight of bulbs and bulblets $\left(236.52 \mathrm{~g} \mathrm{plant}^{-1}\right)$ and the quality characters such as shelf life (12.76 days) and visual scoring (9.10) were recorded the maximum with the treatment combination of $\mathbf{T}_{10}\left(25 \mathrm{tha}^{-1} \mathrm{FYM}+\right.$ Recommended dose of 200:200:200 kg ha ${ }^{-1} \mathrm{NPK}+$ Zinc sulphate@0.50\%+Borax@0.50\% on 30, 60 and 90 DAP), followed by $\mathbf{T}_{9}$.
\end{abstract}

Keywords: tuberose, micronutrients, zinc sulphate, borax, flower yield and shelflife
Volume 3 Issue | - 2019

\section{P Karuppaiah}

Department of Horticulture, Faculty of Agriculture, Annamalai University, India

Correspondence: $\mathrm{P}$ Karuppaiah, Department of Horticulture, Faculty of Agriculture, Annamalai University, Annamalainagar, Tamilnadu, India, Tel 919842321857,

Emailvpkhortic@yahoo.com

Received: June 13,2018 | Published: January 02, 2019

\section{Introduction}

Tuberose (Polianthes tuberosa L.) is an ornamental bulbous plant belongs to the family Amaryllidaceae, native of Mexico. Tuberose is a night-blooming tropical and subtropical bulbous flower crop. Among the ornamental bulbous plants valued for their beauty and fragrance of the flowers, the tuberose occupies a very selected and special position. It consists of about 12 species and an important, popular flower crop being cultivated on a large scale for its scented flower in many parts of the world and in plains of India. The flowers remain fresh for long time and withstand long distance transportation and find the useful place in the flower market. It is a prominent plant in Indian culture and mythology. ${ }^{1}$ Now a days, micronutirents are gradually gaining momentum among the flower growers because of their beneficial nutritional support, better harvest and returns. Best response of African marigold, ${ }^{2,3}$ Chrysanthemum ${ }^{4,5}$ for small quantities of micronutrients have been demonstrated. Micronutrients are to be necessarily taken up by the plants from soil or supplemented through foliar application for good growth and yield of crops and maximizing the efficient use of applied N, P and K. In the absence of the micronutrients, the plants are known to suffer from physiological disorder which eventually leads to imbalanced growth and low yield.

Zinc as a micronutrient, is an essential component of plant enzyme required for energy production, protein synthesis and degradation. Interveinal chlorosis of the older leaves starting at the tip of the margins followed by the white necrotic spotting, shortened internodes, small leaves and stunted growth are characteristic symptoms of zinc deficiency. Zinc is required for the synthesis of IAA, carbohydrate metabolism, protein synthesis, internodes elongation for stem growth and in pollen formation. ${ }^{6}$ Boron is essential for plant growth, new cell division in meristematic tissue, translocation of sugar, starch, nitrogen, phosphorus, certain hormones, synthesis of amino acids and protein, regulations of carbohydrate metabolism, development of phloem etc. In the absence of adequate supply, the leaves may have a thick coppery texture and sometimes curl and become quite brittle. Boron deficiency produces in different parts of plants as a wide variety such as internodes becoming nearly shorter and brittle leaves. Flowering is often totally suppressed and flower often fall. ${ }^{7}$ The demand for increasing flower production will require a thorough knowledge on the relationship between micronutrients and crop growth and flowering. ${ }^{1}$ Keeping above in view, the present investigation on growth, yield and quality of tuberose as influenced by zinc and boron was carried out.

\section{Material and methods}

The experimental site is located at about $20 \mathrm{~km}$ west of Bay of Bengal at $11^{\circ} 24^{\prime}$ 'North latitude and $79^{\circ} 41^{\prime}$ 'East longitude and at an altitude of $+5.79 \mathrm{~m}$ above MSL with the mean maximum temperature of $32.4^{\circ} \mathrm{C}$, mean minimum temperature of $24.1^{\circ} \mathrm{C}$, average relative humidity of 73 per cent and annual rainfall of $1432 \mathrm{~mm}$. The physiochemical analysis of the soil revealed that the soil is clay loam in texture with medium $\mathrm{N}\left(175 \mathrm{~kg} \mathrm{ha}^{-1}\right)$, low $\mathrm{P}_{2} \mathrm{O}_{5}\left(22.50 \mathrm{~kg} \mathrm{ha}^{-1}\right)$, medium $\mathrm{K}_{2} \mathrm{O}\left(107.50 \mathrm{~kg} \mathrm{ha}^{-1}\right)$ and ${ }_{\mathrm{p}} \mathrm{H}$ of 7.8. Eleven treatments were laid out in randomized block design with three replications and the individual plot size was $2 \times 2 \mathrm{~m}$ dimension. Healthy uniform sized bulbs were planted in the field. Two bulbs were planted per pit and later on thinned out to one. Recommended dose of nutrients (NPK@200:200:200 kg ha-1) were applied in the form of Urea $(46.4 \% \mathrm{~N})$, Single Super Phosphate $\left(16.5 \% \mathrm{P}_{2} \mathrm{O}_{5}\right)$ and Muriate of Potash $\left(60.0 \% \mathrm{~K}_{2} \mathrm{O}\right)$ respectively. Full 
dose of $\mathrm{P}_{2} \mathrm{O}_{5}$ and $\mathrm{K}_{2} \mathrm{O}$ were applied at the time of planting as basal while $\mathrm{N}$ was applied in equal split at the time of planting as basal and 30 and 90 days after planting as top dressing. The treatments combinations were formed by foliar application of different concentration of zinc and boron individually such as $\mathbf{T}_{3}\left(25 \mathrm{t} \mathrm{ha} \mathrm{h}^{-1} \mathrm{FYM}+\right.$ Recommended dose of 200:200:200 kg ha ${ }^{-1}$ NPK+Zinc sulphate@0.25\% on 30,60 and 90 DAP), $\mathbf{T}_{4}$ (25tha ${ }^{-1} \mathrm{FYM}^{-}$Recommended dose of 200:200:200 $\mathrm{kg} \mathrm{ha}^{-1} \mathrm{NPK}+$ Zinc sulphate @ $0.50 \%$ on 30,60 and 90 DAP), $\mathbf{T}_{5}\left(25 \mathrm{t} \mathrm{ha}^{-1} \mathrm{FYM}+\right.$ Recommended dose of 200:200:200 $\mathrm{kg} \mathrm{ha}^{-1}$ NPK+Zinc sulphate@0.75\% on 30,60 and 90 DAP), T 6 (25t ha ${ }^{-1}$ FYM+Recommendeddose of 200:200:200 $\mathrm{kgha}^{-1} \mathrm{NPK}+$ Borax@0.25\% on 30, 60 and $90 \mathrm{DAP}), \mathbf{T}_{7}\left(25 \mathrm{tha}^{-1} \mathrm{FYM}+\right.$ Recommended dose of 200:200:200 kg ha-1 NPK+Borax@0.50\% on 30,60 and 90 DAP), $\mathbf{T}_{8}\left(25 \mathrm{t} \mathrm{ha}^{-1}\right.$ FYM+Recommended dose of 200:200:200 kg ha ${ }^{-1}$ NPK+Borax@0.75\% on 30,60 and 90 DAP) and the combination of zinc and boron such as $\mathbf{T}_{\mathbf{9}}\left(25 \mathrm{tha}^{-1} \mathrm{FYM}+\right.$ Recommended dose of 200:200:200 kg ha-1 NPK +Zinc sulphate@0.25\%+Borax@0.25\% on 30, 60 and 90 DAP), $\mathbf{T}_{10}\left(25 \mathrm{~h} \mathrm{~h}^{-1} \mathrm{FYM}+\right.$ Recommended dose of 200:200:200 kg ha ${ }^{-1}$ NPK+Zinc sulphate@0.50\%+Borax@0.50\% on 30,60 and 90 DAP) and $\mathbf{T}_{11}\left(25 \mathrm{tha}^{-1} \mathrm{FYM}+\right.$ Recommended dose of 200:200:200 kg ha-1 NPK + Zinc sulphate@0.75\%+Borax@0.75\% on 30,60 and 90 DAP). The treatment $\mathbf{T}_{2}$ was formed with $25 \mathrm{t} \mathrm{ha}{ }^{-1}$ FYM+Recommended dose of 200:200:200 kg ha-1 NPK without zinc and boron. The control $\left(\mathbf{T}_{1}\right)$ was maintained without any application. The standard package of practices of tuberose was commonly followed. The biometric observations like plant height, number of side shoots per plant, number of leaves per plant, plant spread, leaf area, chlorophyll content and dry matter production, days to fifty per cent flowering, number of spikes per plant, spike length, rachis length, number of flowers per spike, flower length, flower diameter, flower yield per plant, flower yield per plot, flower yield per hectare, shelf life, visual scoring, number of bulbs and bulblets per plant and weight of bulbs and bulblets per plant were observed. The total chlorophyll content was estimated in fully expanded third leaf from the tip by adopting the procedure of Arnon. ${ }^{8}$

\section{Result and discussion}

The result of the present investigation clearly indicated that there was a significant difference on growth, yield and quality of tuberose due to different zinc and boron treatments. Among the different treatments, $\mathrm{T}_{10}\left(25 \mathrm{tha}^{-1} \mathrm{FYM}+\right.$ Recommended dose of 200:200:200 kg ha-1 NPK+Zinc sulphate@0.50\%+Borax@0.50\% on 30,60 and 90 DAP) was found to be the best in all growth and physiological characters viz., plant height $(47.25 \mathrm{~cm})$, number of side shoots per plant (8.89), number of leaves per plant (36.19), plant spread (24.50 $\left.\mathrm{cm}^{2}\right)$, leaf area $\left(42.50 \mathrm{~cm}^{2}\right)$, chlorophyll content $\left(0.918 \mathrm{mg} \mathrm{g}^{-1}\right)$ (Figure 1) and dry matter production (23.15 $\mathrm{g} \mathrm{plant}^{-1}$ ) (Figure 2) followed by $\mathrm{T}_{9}\left(25 \mathrm{tha}^{-1}\right.$ FYM+Recommended dose of 200:200:200 kg ha-1 NPK+Zinc sulphate@0.25\%+Borax@0.25\% on 30,60 and 90 DAP) (Table 1). The significant increase in plant growth and physiological characters with the best treatment might be due to the greater absorption, translocation and the synergistic effect of zinc and boron at appropriate combination for plant growth. These elements also take part in the synthesis of chlorophyll, thereby accumulation of photosynthesis. The micronutrients like zinc and boron might have helped in the nitrogen assimilation and synthesis of proteins and also as catalytic agents in the activation of enzymes. Similar increase in plant growth was obtained by Chaturvedi et al. ${ }^{9}$ in gladiolus by spraying Agromin containing micronutrients viz. $\mathrm{B}, \mathrm{Zn}, \mathrm{Cu}, \mathrm{Mn}, \mathrm{Mg}$ and Mo. Rajput et al. ${ }^{10}$ also reported in their studies that increased plant height in marigold might be due to the combined effect of zinc and boron. The increase in leaf number might be due to continuous availability of zinc and boron and their involvement in nitrogen metabolism, protein synthesis and hormonal translocation. Hence, zinc and boron might have complemented higher leaf production. The findings in the present study were also supported by Barman and $\mathrm{Pal}^{11}$ and Nath and Biswas ${ }^{12}$ in tuberose, Iftikhar Ahmad et $\mathrm{al}^{13}$. in rose and Chaturvedi et al. ${ }^{9}$ and Jyoti Sharma et al. ${ }^{14}$ in gladiolus. The higher carbohydrate accumulation in leaves facilitated by a favorably influenced combination of zinc and boron application might have lead to higher photosynthetic activities and ultimately resulting in an increased plant spread and leaf area. The plant spread and leaf area is more directly related to the photosynthetic efficiency as reported by Swapna ${ }^{15}$ in African marigold and similar observations were already made by Hardeep Kumar et al. ${ }^{16}$ in tuberose and Rajiv Kumar et al. ${ }^{17}$ in gladiolus. The significant variation in chlorophyll content might be due to the positive effects of zinc and boron and its appropriate combination as reported by Hardeep Kumar et al. ${ }^{16}$ in tuberose and Balakrishnan $^{2}$ in African marigold.

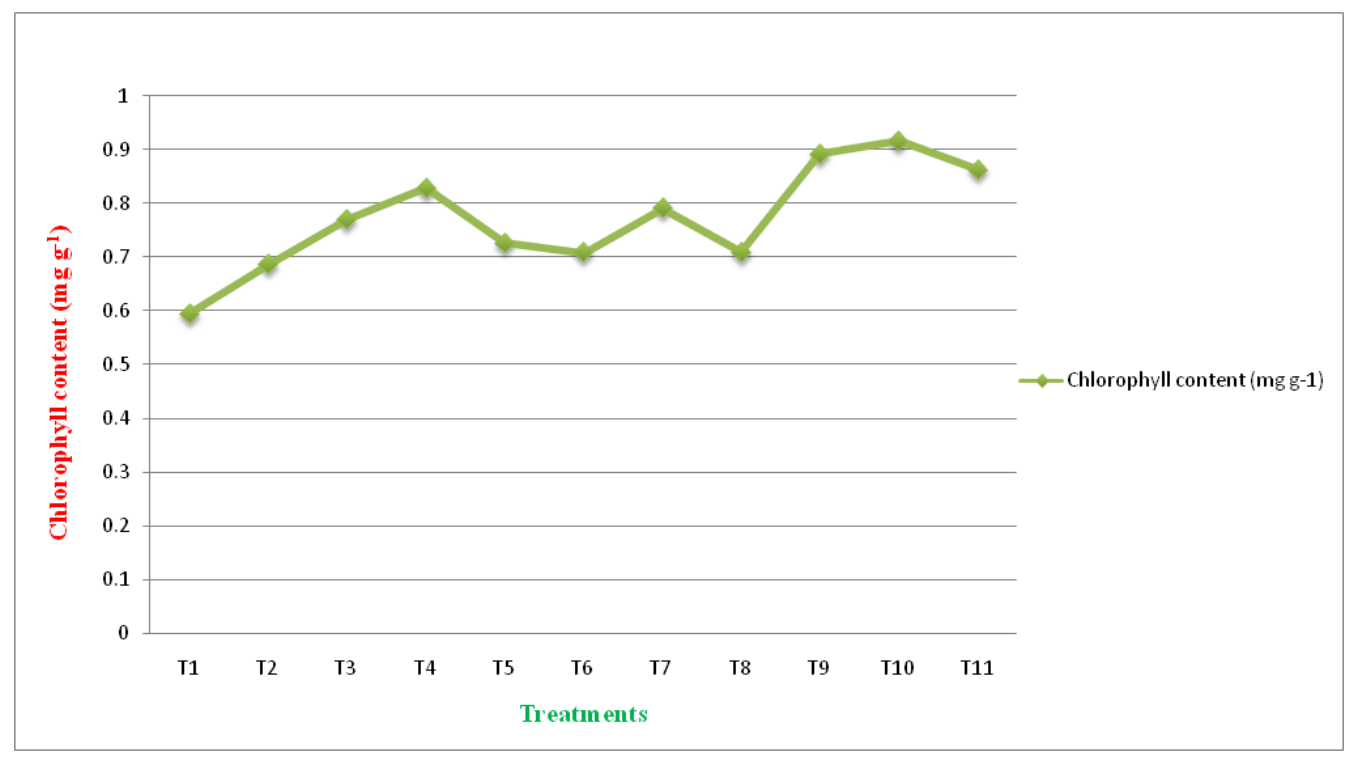

Figure I Effect of zinc and boron on chlorophyll content $\left(\mathrm{mgg}^{-1}\right)$ of tuberose (Polianthes tuberosa L.) cv. Prajwal. 


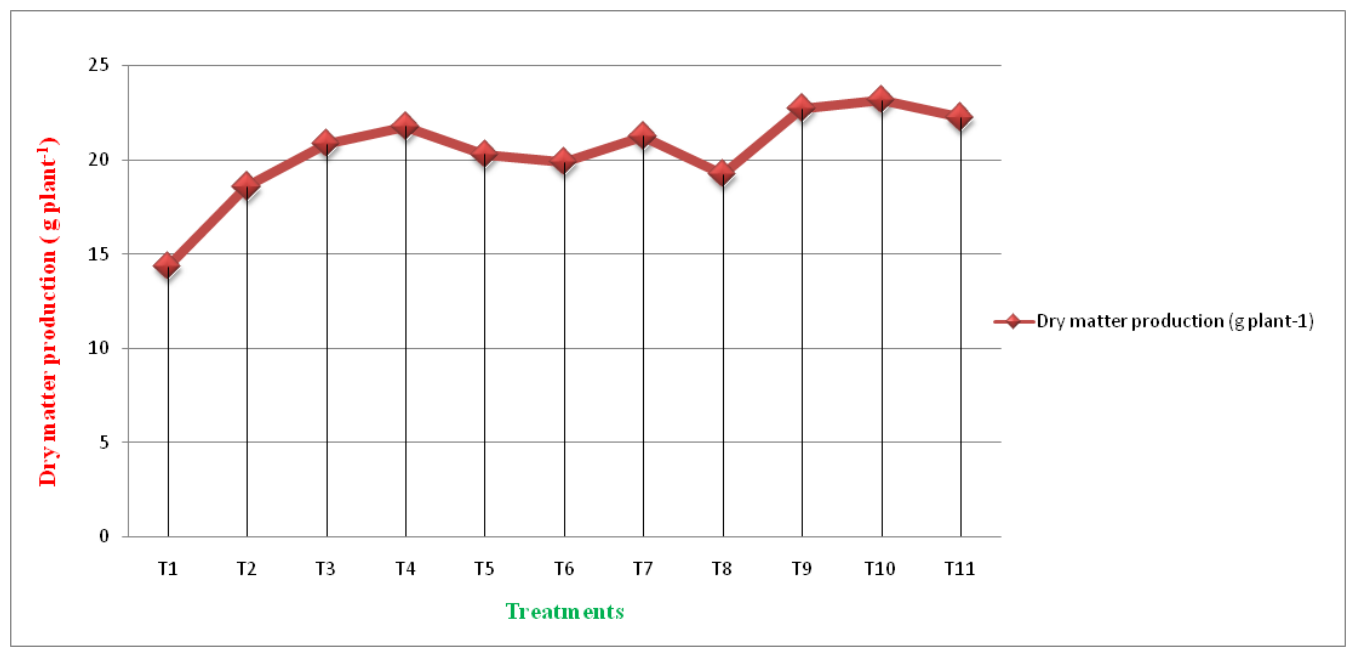

Figure 2 Effect of zinc and boron on dry matter production (g plant ${ }^{-1}$ ) of tuberose (Polianthes tuberosa L.) cv. Prajwal

Table I Effect of zinc and boron on growth attributes of tuberose (Polianthes tuberosa L.) cv. Prajwal

\begin{tabular}{|c|c|c|c|c|c|}
\hline Treatments & $\begin{array}{l}\text { Plant } \\
\text { height }(\mathbf{c m})\end{array}$ & $\begin{array}{l}\text { Number of } \\
\text { side shoots } \\
\text { per plant }\end{array}$ & $\begin{array}{l}\text { Number } \\
\text { of leaves } \\
\text { per plant }\end{array}$ & $\begin{array}{l}\text { Plant spread }\left(\mathrm{cm}^{2}\right) \\
\text { north- south }\end{array}$ & $\begin{array}{l}\text { Leaf } \\
\text { area } \\
\left(\mathrm{cm}^{2}\right)\end{array}$ \\
\hline $\mathbf{T}_{2}-25 \mathrm{t} \mathrm{ha}^{-1} \mathrm{FYM}+$ Recommended dose of $200: 200: 200 \mathrm{~kg} \mathrm{ha}^{-1}$ NPK & 42.45 & 6.01 & 23.39 & 18.66 & 39.52 \\
\hline $\begin{array}{l}\mathbf{T}_{3}-25 \mathrm{th}^{-1} \text { FYM+Recommended dose of } 200: 200: 200 \mathrm{~kg} \mathrm{ha}^{-1} \\
\text { NPK+Zinc sulphate@0.25\% on } 30,60 \text { and } 90 \text { DAP }\end{array}$ & $44.5 \mathrm{I}$ & 7.10 & 27.82 & 21.23 & 40.85 \\
\hline $\begin{array}{l}\mathbf{T}_{4}-25 \mathrm{tha}^{-1} \mathrm{FYM}+\text { Recommended dose of } 200: 200: 200 \mathrm{~kg} \mathrm{ha}^{-1} \\
\text { NPK+Zinc sulphate@0.50\% on } 30,60 \text { and } 90 \text { DAP }\end{array}$ & 45.59 & 7.83 & 30.16 & 22.54 & 41.53 \\
\hline $\begin{array}{l}\mathbf{T}_{5}-25 \mathrm{tha}^{-1} \mathrm{FYM}+\text { Recommended dose of } 200: 200: 200 \mathrm{~kg} \mathrm{ha}^{-1} \\
\text { NPK+Zinc sulphate@0.75\% on 30,60 and } 90 \text { DAP }\end{array}$ & 43.89 & 6.73 & 27.84 & 20.61 & 40.58 \\
\hline $\begin{array}{l}\text { T }_{6}-25 \mathrm{tha}^{-1} \mathrm{FYM}+\text { Recommended dose of } 200: 200: 200 \mathrm{~kg} \mathrm{ha}^{-1} \\
\text { NPK+Borax @0.25\% on 30,60 and } 90 \text { DAP }\end{array}$ & 43.28 & 6.36 & 25.73 & 19.95 & 40.21 \\
\hline $\begin{array}{l}\mathbf{T}_{7}-25 \mathrm{ha}^{-1} \mathrm{FYM}+\text { Recommended dose of } 200: 200: 200 \mathrm{~kg} \mathrm{ha}^{-1} \\
\text { NPK+Borax @0.50\% on } 30,60 \text { and } 90 \text { DAP }\end{array}$ & 45.10 & 7.46 & 29.85 & 21.88 & 41.18 \\
\hline $\begin{array}{l}\mathbf{T}_{8}-25 \mathrm{ha}^{-1} \mathrm{FYM}+\text { Recommended dose of } 200: 200: 200 \mathrm{~kg} \mathrm{ha}^{-1} \\
\text { NPK+Borax@ 0.75\% on 30,60 and } 90 \text { DAP }\end{array}$ & 42.83 & 6.98 & 24.26 & 19.28 & 39.86 \\
\hline $\begin{array}{l}\text { T }_{9}-25 \mathrm{th}^{-1} \text { FYM+Recommended dose of } 200: 200: 200 \mathrm{~kg} \mathrm{ha}^{-1} \\
\text { NPK+Zinc sulphate@0.25\%+Borax@0.25\% on } 30,60 \text { and } 90 \text { DAP }\end{array}$ & 46.72 & 8.53 & 33.54 & 23.33 & 42.05 \\
\hline $\begin{array}{l}\mathbf{T}_{10}-25 \mathrm{tha}^{-1} \mathrm{FYM}+\text { Recommended dose of } 200: 200: 200 \mathrm{~kg} \mathrm{ha}^{-1} \\
\text { NP+Zinc sulphate@0.50\%+Borax@ } 0.50 \% \text { on } 30,60 \text { and } 90 \text { DAP }\end{array}$ & 47.25 & 8.89 & 36.19 & 24.50 & 42.50 \\
\hline $\begin{array}{l}\mathbf{T}_{11}-25 \mathrm{th}^{-1} \mathrm{FYM}+\text { Recommended dose of } 200: 200: 200 \mathrm{~kg} \mathrm{ha}{ }^{-1} \\
\text { NPK+Zinc sulphate@0.75\%+Borax@0.75\% on } 30,60 \text { and } 90 \text { DAP }\end{array}$ & 46.17 & 8.16 & 32.93 & 23.16 & 41.82 \\
\hline S.Ed & 0.24 & 0.17 & 0.46 & 0.32 & 0.16 \\
\hline$C D(P=0.05)$ & 0.51 & 0.34 & 0.96 & 0.64 & 0.32 \\
\hline
\end{tabular}

Application of zinc and boron significantly influenced the flowering characters of tuberose. Yield is a complex phenomenon which can be controlled both by morphological and physiological parameters and it can also be manipulated by either genetic factors (or) cultural operations. In the present study, the yield characters viz., days to fifty per cent flowering (90.47 days), number of spikes per plant (4.55), spike length $(95.42 \mathrm{~cm})$, rachis length $(28.89 \mathrm{~cm})$, number of flowers per spike (41.52), flower length $(6.66 \mathrm{~cm})$, flower diameter $(4.03 \mathrm{~cm})$, hundred flowers weight (94.73 g) (Table 2), flower yield per plant (128.65 $\left.\mathrm{g} \mathrm{plant}^{-1}\right)$, flower yield per plot $\left(1.54 \mathrm{~kg} \mathrm{plot}^{-1}\right)$, flower yield per hectare (14.28 tha $\left.\mathrm{a}^{-1}\right)$, number of bulbs and bulblets (18.23) and weight of bulbs and bulblets (236.52 g plant $\left.^{-1}\right)$ (Table 3 ) were observed in the treatment $T_{10}\left(25\right.$ tha $^{-1}$ FYM+Recommended dose of 200:200:200 $\mathrm{kg} \mathrm{ha}^{-1} \mathrm{NPK}+$ Zinc sulphate@0.50\%+Borax@0.50\% on 30,60 and 90 DAP), followed by $\mathrm{T}_{9}\left(25 \mathrm{tha}^{-1} \mathrm{FYM}+\right.$ Recommended dose of 200:200:200 kg ha ${ }^{-1}$ NPK+Zinc sulphate@0.25\%+Borax@0.25\% on 30,60 and $90 \mathrm{DAP})$. The minimum recorded in control $\left(\mathrm{T}_{1}\right)$. The increase in flowering attributes might due to the beneficial role of micronutrients in enhancing the translocation of carbohydrates, minerals and amino acids from the site of the synthesis to the flowering 
tissue especially on flowers as reported by Rajiv $\operatorname{Kumar}^{17}$ in gladiolus, Balakrishnan et al. ${ }^{2}$ in African marigold and Naveen Kumar et al. ${ }^{18}$ in chrysanthemum. The significantly increased flowering characters might be due to the combined effect of micronutrients especially zinc and boron as reported by Reddy and Chaturvedi ${ }^{19}$ in gladiolus. The favorable positive effect of zinc and boron in yield attributes might be due to their involvement in synthesis and mobility of photo synthates, minerals and amino acids from the source to sink that enhance the per plant and per hectare yield. The improvement in yield due to zinc and boron application might basically be due to the enhanced photosynthetic and other metabolic activities related to cell division and elongation as reported by Swapna ${ }^{15}$ in African marigold and Jyoti Sharma et al. ${ }^{14}$ in gladiolus. The interaction between zinc and boron is known to increase the plant height, number of leaves per plant, plant spread and leaf area that might have led to enhance the rate of photosynthesis. As a result of this, availability of metabolites to the developing bulbs and bulblets might be increased, thereby led to increase in the number of bulbs and bulblets count and their weight. The present results are in agreement with findings of Hardeepkumar et al. ${ }^{16}$ in tuberose, Karuppaiah ${ }^{20}$ in French marigold and Swapna ${ }^{15}$ in African Marigold.

Table 2 Effect of zinc and boron on flowering attributes of tuberose (Polianthes tuberosa L.) cv. Prajwal

\begin{tabular}{|c|c|c|c|c|c|c|c|c|}
\hline Treatments & $\begin{array}{l}\text { Days to fifty } \\
\text { per cent } \\
\text { flowering }\end{array}$ & $\begin{array}{l}\text { Number } \\
\text { of spikes } \\
\text { per plant }\end{array}$ & $\begin{array}{l}\text { Spike } \\
\text { length } \\
(\mathrm{cm})\end{array}$ & $\begin{array}{l}\text { Rachis } \\
\text { length } \\
(\mathrm{cm})\end{array}$ & $\begin{array}{l}\text { Number } \\
\text { of flowers } \\
\text { per spike }\end{array}$ & $\begin{array}{l}\text { Flower } \\
\text { length } \\
(\mathrm{cm})\end{array}$ & $\begin{array}{l}\text { Flower } \\
\text { diameter } \\
(\mathrm{cm})\end{array}$ & $\begin{array}{l}\text { Hundred } \\
\text { flowers } \\
\text { weight (g) }\end{array}$ \\
\hline T2 & 97.51 & 3.13 & 90.41 & 23.52 & 34.78 & 5.28 & 3.3 & 90.28 \\
\hline T4 & 92.54 & 4.11 & 93.94 & 27.21 & 39.17 & 6.17 & 3.76 & 93.3 \\
\hline T5 & 95.08 & 3.64 & 91.9 & 25.18 & 36.56 & 5.62 & 3.45 & 91.63 \\
\hline T6 & 96.4 & 3.39 & 91.15 & 24.46 & 35.87 & 5.53 & 3.42 & 97.06 \\
\hline T7 & 93.15 & 3.93 & 93.33 & 26.54 & 38.34 & 5.96 & 3.73 & 92.77 \\
\hline TIO & 90.47 & 4.55 & 95.42 & 28.89 & 41.52 & 6.66 & 4.03 & 94.73 \\
\hline TII & 91.83 & 4.28 & 94.51 & 27.79 & 39.98 & 6.34 & 3.87 & 93.81 \\
\hline S.Ed & 0.32 & 0.05 & 0.2 & 0.25 & 0.36 & 0.06 & 0.02 & 0.21 \\
\hline$C D(P=0.05)$ & 0.64 & 0.1 & $0.4 I$ & 0.5 & 0.73 & 0.13 & 0.04 & 0.43 \\
\hline
\end{tabular}

Table 3 Effect of zinc and boron on yield and quality attributes of tuberose (Polianthes tuberosa L.) cv. Prajwal

\begin{tabular}{|c|c|c|c|c|c|c|c|}
\hline Treatments & $\begin{array}{l}\text { Flower } \\
\text { yield per } \\
\text { plant (g) }\end{array}$ & $\begin{array}{l}\text { Flower yield } \\
\text { per plot } \\
\text { (kg plot-I) }\end{array}$ & $\begin{array}{l}\text { Flower yield } \\
\text { per hectare } \\
\text { (t ha-I) }\end{array}$ & $\begin{array}{l}\text { Number of bulbs } \\
\text { and bulblets per } \\
\text { plant }\end{array}$ & $\begin{array}{l}\text { Weight of bulbs } \\
\text { and bulblets per } \\
\text { plant }(\mathrm{g})\end{array}$ & $\begin{array}{l}\text { Shelf life } \\
\text { (days) }\end{array}$ & $\begin{array}{l}\text { Visual } \\
\text { scoring }\end{array}$ \\
\hline TI & 69.84 & 0.83 & 7.76 & 10.94 & 178.08 & 7.95 & 6.94 \\
\hline T2 & II5.54 & 1.29 & 12.88 & 16.13 & 209.36 & 9.76 & 7.58 \\
\hline T3 & 121.32 & 1.38 & 13.6 & 16.86 & 220.59 & 11.12 & 8.42 \\
\hline T4 & 124.24 & 1.45 & 13.86 & 17.35 & 226.94 & 11.54 & 8.69 \\
\hline
\end{tabular}

With regards to quality aspects viz., visual scoring (9.10) and shelf life (12.76 days) (Table 3 ), the treatment $T_{10}$ was found to be excellent treatment followed by $\mathrm{T}_{9}$. Extension in shelf life of flowers is a key issue in post harvest management of flowers and post harvest management assumes greater significance in flowers like tuberose which is highly sensitive to ethylene. Better quality of tuberose flower might be due to higher carbohydrate, other essential nutrients, plant growth regulators and enzymes deposition in flower cells by the zinc and boron physiological role which resulted in production of good quality attractive flowers. This good quality flower suppresses ethylene and abcisic acid and prolong the shelf life and appearance of flowers. Similar findings were given by Tisdale et al. ${ }^{21}$ in orchids, Bhagyalakshmamma $^{22}$ in gerbera, Karuppaiah ${ }^{20}$ in French marigold and Jyoti Sharma et al. ${ }^{14}$ in gladiolus.
From the above results, it is concluded that the $\mathrm{T}_{10}\left(25 \mathrm{tha}^{-1}\right.$ FYM + Recommended dose of 200:200:200 kg ha-1 NPK+Zinc sulphate@0.50\%+Borax@0.50\% on 30,60 and 90 DAP) was found to be beneficial and economically feasible for the effective cultivation of tuberose (Polianthes tuberosa L.) cv. Prajwal under open field condition in the coastal ecosystem.

\section{Acknowledgments}

None.

\section{Conflicts of interest}

Authors declare that there is no conflicts of interest. 


\section{References}

1. Ganesh S, K Sooriannathasundaram, M Kannan. Studies on effect of plant growth regulators and micronutrients on growth, floral characters and yield of tuberose (Polianthes tuberosa L.). cv. Prajwal. The Asian Journal of Horticulture. 2013;8(2):696-700.

2. Balakrishnan V, M Jawaharlal, T Senthilkumar, et al. Response of micronutrients on flowering, yield and xanthophylls content in African marigold. Journal of Ornamental Horticulture. 2007;10(3):153-156.

3. Arivazhagan, A. Effect of micronutrients on growth, yield and quality of African marigold. Cv. Maxima yellow. M. Sc (Ag.) Hort. Thesis, department of horticulture, faculty of agriculture, annamalai university, annamalainagar, Tamilnadu, India; 2012 .

4. Annasamy K. Effect of micronutrients on growth, yield and quality of chrysanthemum (Dendrathemum grandiflorum Tzeuleu.). M. Sc (Ag.) Hort. thesis, department of horticulture, faculty of agriculture, annamalai university, annamalainagar, tamilnadu, India; 2010

5. Manikandan CKEffect of bioregulators and FeSo4 on growth, yield and quality of Crossandra (Crossandra infundibuliformis L.). M. Sc (Ag) Hort. Thesis, department of horticulture, faculty of agriculture, annamalai university, Annamalainagar Tamilnadu, India; 2013.

6. Shukla AKBS, Dwivedi VK, Singh, et al. Macro role of micronutrients. Indian J Fert.2009;5(5):11-12.

7. Pratt HK, JD Goeschi. Boron physiological roles in plants. Ann Rev Plant Physiol. 1999;20:541-584.

8. Arnon DI. Copper enzymes in isolated chloroplasts poly peroxidise in Beta vulgaris. Pl Physiol. 1949;24:1-45.

9. Chaturvedi OP, IN Shukla, AR Singh. Effect of agromin on growth and flowering in gladiolus. Haryana J Hort Sci. 1986;18(3\&4):196-199.

10. Rajput D, K Megh Naresh, PC Srivastava, et al. Effect of S, B and $\mathrm{Zn}$ application and their interactions on growth, yield and nutrients uptake of Tagetes minuta L. Indian Perfumers. 2003;47(1):91-97.

11. Barman D, P Pal. A note on effect of micronutrients on growth and yield of tuberose cv. Single. Indian J. Hort. 1993;6(1):69-70.
12. Nath MR, J Biswas. Studies on effect of boran on vegetative and reproductive growth in tuberose (Polianthes tuberosa) cv. Single. The Orissa J Hort Sci. 2002;6(2):301-305.

13. Iftikhar Ahmad M, Aslam Khan M, Qasin MA, et al. Growth, yield and quality of Rosa hybrida L. as influenced by various micronutrients. Pak J Agri Sci. 2010;47(1):5-12.

14. Jyoti Sharma, AK Gupta, Chandan Kumar, et al. Influence of zinc, calcium and boron on vegetative and flowering parameters of gladiolus cv. Aldebran. The Bioscan. 2013;8(4):1153-1158.

15. Swapna C. Investigation on production system efficiency of precision farming in comparison with conventional system in marigold (Tagetes erecta L).Ph.D Thesis.Tamilnadu Agricultural University,Coimbatore, Tamilnadu, India; 2010.

16. Hardeep Kumar, Sukhbir Singh VP, Ahlawat, et al. Influence of nitrogen and zinc application on growth, flowering and chlorophyll content of tuberose (Polianthes tuberosa L.). cv. Double. Haryana J Hort Sci. 2003;32(2):212-215

17. Rajiv Kumar GN, Singh, RL Misra. Effect of boran, calcium and zinc on gladiolus. Journal of Ornamental Horticulture. 2003;6(2):104-106.

18. Naveenkumar PRL, Misra SR, Dhiman M, et al. Effect of micronutrient sprays on growth and flowering of chrysanthemum. Indian J Agric. 2009;79(6):426-428

19. Reddy AGK, OP Chaturvedi. Effect of zinc, calcium and boron on growth and flowering in gladiolus cv. Red Majesty. Crop Research. 2009;38:135-137.

20. Karuppaiah P. Effect of spacing and nutrient levels on flower yield, carotenoid content, nutrient uptake and residual soil fertility in French marigold (Tagtes patula L.). Internat J agric Sci. 2006;2(2):375-376.

21. Tisdale SL, WL Nelson, ID. Beaton. Elements required in plant nutrition. Soil fertility and fertilizers, 4th edn.1985;27:33.

22. Bhagyalakshmamma BS. Effect of micronutrients on growth, yield, quality and post harvest life of gerbera (Gerbera jamesonii Hook.) grown under cover. M.Sc. (Hort.) Thesis, University of Agricultural Sciences, Bangalore; 1998. 